\title{
ДЕВІАНТНА ПОВЕДІНКА ПРАВОСЛАВНОГО ПАРАФІЯЛЬНОГО ДУХОВЕНСТВА КИЇВСЬКОЇ ЄПАРХІЇ У ХІХ - НА ПОЧАТКУ ХХ ст.
}

Анотація: у статті розглядається девіантна поведінка православного парафіяльного духовенства Київської єпархії у XIX - на початку XX ст. Встановлено найпоширеніші порушення кліриками соціальних і канонічних норм та санкції церковної адміністрації. Правопорушення кліриків в основному стосувалися виконання ними службових обов'язків або неналежної моральної поведінки. Відзначається, що переважна більшість справ, які стосувалися священно- $i$ церковнослужителів, підлягала не світському, а окремому церковному суду. Встановлено, що становим судом у другій половині ХІХ ст. засуджувався приблизно 1\% від загальної кількості парафіяльного духовенства єпархії.

Ключові слова: православне парафіяльне духовенство, девіантна поведінка, иерковний суд, Київська єпархія, духовна консисторія

3 огляду на специфічність «професії», духовенство, на відміну від будь-якої іншої верстви, завжди мало відповідати своїй соціальній ролі не тільки при виконанні безпосередніх обов'язків, а й у вільний час. Особливість повсякденного життя священнослужителів полягала у необхідності контролювати свої вчинки, адже священик мав користуватися повагою, бути прикладом, моральним авторитетом для вірян і загалом відповідати уявленням суспільства про ідеального пастиря. Слідувати цьому взірцевому образу було під силу не всім представникам духовного стану. Будь-який вчинок священнослужителя ставав публічним, а навіть незначний проступок, який допускав клірик у побуті, сімейному житті розглядався громадою «під лупою» та був предметом пересудів і сприймався як прояв непрофесіоналізму. Часто негідний вчинок одного священика кидав тінь на весь духовний стан. Церковна адміністрація всіляко намагалася боротися 3 девіантною поведінкою священно- і церковнослужителів, застосовуючи різноманітні санкції.

В останнє десятиліття вивчення повсякденного життя різних категорій населення отримує все більшу популярність серед науковців. Дослідники звертаються до різних аспектів повсякденності, у тому числі і до поведінкових практик і моральності окремих груп населення. Разом з тим в історичній школі проблема девіантної поведінки православного кліру значною мірою залишається «за кадром», адже детально не розглядалася. Варто відзначити праці вітчизняних дослідників О.Тарасенка

\footnotetext{
* Тацієнко Віталій Сергійович - кандидат історичних наук, доцент кафедри історії України Уманського державного педагогічного університету імені Павла Тичини (Умань, Україна);

ORCID: https://orcid.org/0000-0003-3372-9765; e-mail: tatsiyenko1990@ukr.net

${ }^{1}$ Тарасенко 0. Девіантна поведінка парафіяльного духовенства (за матеріалами Чернігівської єпархії кінця XVIII - першої половини XIX ст. // Сіверянський літопис. 2012. № 5-6. С. 42-49.
} 
Є. Захарченка 2 . Частіше вчені побіжно торкалися означеної теми у контексті дослідження більш масштабних соціальних явищ, зокрема, вивчення повсякденного життя православного духовенства, його правового статусу, варто виділити праці В. Меші ${ }^{3}$, Б. Опрі ${ }^{4}$, В. Тацієнка ${ }^{5}$. Особливий інтерес викликає регіональний аспект означеної проблеми.

Метою статті є спроба простежити девіантну поведінку православного парафіяльного духовенства Київської єпархії та відповідні санкції церковної адміністрації у XIX - на початку XX ст.

Переважна більшість справ, що стосувалися священно- і церковнослужителів підлягала не світському, а окремому церковному суду (як то: неналежне виконання обов'язків, негідна поведінка, скарги на кліриків як світських, так і духовних осіб, суперечки між членами причту щодо розподілу прибутків чи користування церковними землями, будинками й ін.). Такий судовий розгляд проходив у духовній консисторії тієї єпархії, до якої належав клірик. Центральною фігурою єпархіального суду був правлячий архієрей, який здійснював судові функції за допомогою консисторії, яка проводила всю підготовчу роботу та надавала керівнику єпархії проекти готових рішень. Традиційне церковне судочинство не змінилося судовою реформою 1864 р. До компетенції світського суду належали: кримінальні злочини; порушення державних законів; справи між духовенством, кліриками і мирянами про невиконання договору чи зобов'язань, порушення прав збитками, самоправним заволодінням майном тощо 6 . Якщо вчинок клірика підпадав під розгляд цивільного судочинства, то початкове розслідування все одно відбувалося у духовному відомстві за участі поліцейського. Якщо виявлялися факти, які свідчили про можливу причетність священно-, церковнослужителя до скоєного правопорушення, справа передавалася світському суду. За необхідності термінового розгляду справи, поліція проводила слідство, запросивши духовного депутата. У виняткових випадках слідчі дії поліції могли відбуватися і без представника духовного відомства7. Церковна судова система в загальних рисах залишалася у тому вигляді, в якому сформувалася ще на початку синодального періоду. Церковний суд у XIX - на початку XX ст. був застарілим.

Варто зауважити, що кримінальні злочини духовенство здійснювало вкрай рідко. За даними Б. Міронова щодо злочинності за станами (співвідношення частки стану до загальної кількості засуджених та чисельності верстви в загальній структурі населення) у 1858-1897 рр. перше місце належало купцям (2,0), друге - міщанам і ремісникам $(1,7)$,

\footnotetext{
${ }^{2}$ Zaharchenko E. «We pour, because of this he drinks»: deviant behaviour of the parish clergy in the $19^{\text {th }}$ century (on the material of Kharkiv diocese) // Вісник Харківського національного університету імені В.Н. Каразіна. 2014. № 1119. С. 76-78; Захарченко Є.Ю. Родина парафіяльного священика Харківської єпархії у XIX - на початку XX ст.: Дис... канд. іст. наук: 07.00.01 - Історія України. Харків, 2015. 213 арк.

${ }^{3}$ Меша В.Г. Правовий статус духовенства України другої половини XIX століття // Вісник Східноукраїнського національного Університету імені Володимира Даля. 2008. № 11 (129). С. 167-172.; Меша В.Г. Конфесійний та суспільний аспекти розвитку православної церкви в Україні 1875-1900 років: Автореф. дис... д-ра іст. наук: 07.00.01 - Історія України. Донецьк, 2009. 41 с.

${ }^{4}$ Опря Б.О. Повсякденне життя православного парафіяльного сільського духовенства Правобережної України (1860-ті - 1917 р.): Дис... канд. іст. наук: 07.00 .01 - Історія України. Кам'янець-Подільський, 2011. 275 арк.

${ }^{5}$ Тацієнко В.С. Повсякденне життя православного парафіяльного духовенства Київської єпархії в кінці XVIII на початку XX ст.: Дис... канд. іст. наук: 07.00.01 - Історія України. Умань, 2016. 268 арк.

${ }^{6}$ Устав духовных консисторий. Санкт-Петербург: Синодальная типография, 1843. С. 62.

${ }^{7}$ Ibidem.
} 
третє - дворянам і чиновникам $(1,5)$, четверте - селянам $(0,9)$, п'яте - духовенству $(0,3-$ $0,4)^{8}$. В 1879 р. у Правобережній Україні мировими суддями було засуджено 3244 особи. 3 них: селян - 2104; міщан - 692; нижчих відставних чинів та членів їх сімей - 444; купців 3 ; духовенства $-1^{9}$. Як бачимо духовний стан істотно поступався по криміногенності всім іншим.

у «Статуті духовних консисторій» закріплювалась багатоступенева система покарань, що застосовувалась до духовенства залежно від провини. Усього визначалося 12 позицій: 1) позбавлення сану з виключенням із духовного стану; 2) позбавлення сану та переведення на нижчі посади, але після наступних негідних вчинків передбачалося виключення 3 духовного відомства; 3) тимчасова заборона священнослужіння 3 позбавленням місця та переведення у причетники, а за умови каяття та виправлення - дозвіл на священнослужіння; 4) тимчасова заборона священнослужіння без усунення від посади, але 3 накладенням єпитимії у монастирі або за місцем служби; 5) тимчасове перебування в Архієрейському домі або монастирі; 6) позбавлення місця; 7) виключення за штат; 8) посилений нагляд; 9) грошове стягнення; 10) поклони; 11) сувора або звичайна догана; 12) зауваження ${ }^{10}$.

Таким чином найм'якішими покараннями були зауваження та догана. Призначалися вони найчастіше за не надто значні службові чи побутові проступки. Наприклад, у 1899 р. священик-вдівець м. Радомишля I. Котляр отримав сувору догану «за держание в услужении в своем доме женщины предосудительного поведения» ${ }^{11}$. У 1908 р. священик Маковський, що завідував парафіяльною школою у с. Шубівка Київського повіту, отримав сувору догану за недбале ставлення до освітніх обов'язків ${ }^{12}$. М'яким покаранням було призначення поклонів священно- і церковнослужителям. Так, у 1844 р. диякону с. Матусів Черкаського повіту М. Кейзеру за те, що бажаючи пригостити селян горілкою у нічний час, пішов до корчми, було призначено 300 поклонів на тиждень при благочинному та парафіяльному священику. Окрім того, він підпискою зобов'язувався утримуватися від подібної поведінки ${ }^{13}$. У 1852 р. священику с. Веселого Кута Таращанського повіту О. Лісинському за помічену в його церкві «нечистоту на престоле, около святых даров і в ящике хранящем святое миро», а також за нетверезість було призначено 100 поклонів ${ }^{14}$.

Інколи практикувався посилений нагляд за кліриками. Зокрема, псаломщик с. Юрківці I. Кравченко за конфлікт з селянином був покараний тримісячним перебуванням у КиєвоТроїцькому монастирі та переведений до іншої парафії - Успенської церкви м. Мошни. Він підлягав пильному нагляду місцевого благочинного. У 1908 р. церковнослужитель звернувся до митрополита Флавіана (Городецького) 3 проханням звільнити його від цього

\footnotetext{
${ }^{8}$ Миронов Б.Н. Социальная история России периода империи (XVIII - начало XX в.): В 2 т. Санкт-Петербург: Дмитрий Буланин, 2000. Т. 1. С. 95.

${ }^{9}$ Опря Б.О. Повсякденне життя православного парафіяльного сільського духовенства... Арк. 48.

${ }^{10}$ Устав духовных консисторий... С. 71-73.

${ }^{11}$ Центральний державний історичний архів України в м. Києві (ЦДІАК України). Ф. 127. Оп. 955. Спр. 466. Арк. 12.

${ }^{12}$ Степаненко $\Gamma$. Культурно-просвітянська діяльність православного духовенства Наддніпрянської України (друга половина XIX - початок XX ст.) // Український історичний збірник. 2000. Вип. 3. С. 141.

${ }^{13}$ ЦДІАК України. Ф. 127. Оп. 855. Спр. 8. Арк. 7-8.

${ }^{14}$ ЦДІАК України. Ф. 127. Оп. 896. Спр. 427. Арк. 1.
} 
посиленого контролю, під яким перебував 5 років. Зрештою, консисторія прийняла позитивне рішення щодо звернення причетника ${ }^{15}$.

Найбілыш поширеними санкціями єпархіальної адміністрації були штрафи та тимчасова заборона священнослужіння з переведенням у причетники або відправленням у монастир. Наприклад, у 1902 р. єпархіальна адміністрація оштрафувала 30-ма руб. священика с. Закриниччя Таращанського повіту І. Лисовецького за недотримання правил розподілу кружечного прибутку та несправедливе розмежування земельних угідь між членами причту ${ }^{16}$. у 1913 р. єпархіальна адміністрація оштрафувала на 25 руб. священиків сіл Стрижавка Таращанського повіту, Товстий Ліс Радомишльського повіту, Сахнівка та Вахутинець Канівського повіту «за напрасное беспокойство начальства просьбою о перемещении в другой приход» $»^{17}$ Штрафи з кліриків стягувалися на користь єпархіального опікунства.

Мінімальний строк перебування у монастирі складав два тижні, максимальний, як правило, два, іноді, три місяці. Зокрема, священик С. Ковальський перебував в архієрейському домі за побиття парафіянина ${ }^{18}$. Дячок с. Гопчиця І. Козакевич у клірових відомостях за 1843 р. характеризувався «поведения худого» і за неналежну поведінку був покараний двомісячним перебуванням у митрополичому домі ${ }^{19}$. Але найчастіше таке покарання отримували клірики за зловживання алкоголем. Так, у 1850 р. диякона с. Житні Гори Г. Іванчу за пияцтво було відправлено на два місяці до Мошногірського монастиря та прийнято рішення про переведення до іншої парафії ${ }^{20}$.

Найсуворіше покарання - позбавлення сану 3 виключенням із духовного стану застосовувалося досить рідко. Найчастіше це стосувалося осіб, які скоювали кримінальні злочини, або ж на яких не діяли виправні заходи, і вони неодноразово засуджувалися церковним судом. Проте церковне керівництво не зупинялося і перед радикальними заходами. 3 духовного стану виключалися священно- та церковнослужителі, на яких не діяли виправні та каральні міри й які продовжували поводити себе невідповідно сану, ганьбили його. Наприклад, у 1831 р. митрополитом Євгенієм (Болховітіновим) за неналежне виконання обов'язків, пияцтво, негідну поведінку позбавлено сану та відправлено у розпорядження губернського правління 13 священиків, 12 - назавжди переведено у причетники, 1 священика (вдівця) назавжди відіслано до Бєліловського монастиря на послух із забороною священнослужіння ${ }^{21}$.

У звітах київських митрополитів Св. Синоду про стан єпархії відзначалося, що загалом моральність православного духовенства залишалася на досить високому рівні. Зокрема, у 1865 р. митрополит Арсеній (Москвін) відзначав належний моральний стан кліру. Того ж року за результатами розгляду консисторією 135 справ про поведінку та вчинки кліриків: одного священика позбавлено сану, ще одного переведено у причетники, а 27 осіб, у

\footnotetext{
${ }^{15}$ ЦДІАК України. Ф. 127. Оп. 786. Спр. 599. Арк. 1-5.

${ }^{16}$ ЦДІАК України. Ф. 127. Оп. 876. Спр. 873. Арк. 22.

${ }^{17}$ Распоряжение епархиального начальства // Киевские епархиальные ведомости. 1913. № 25. С. 386; Распоряжения епархиального начальства // Киевские епархиальные ведомости. 1913. № 26. С. 413.

${ }^{18}$ ЦДІАК України. Ф. 127. Оп. 402. Спр. 37. Арк. 16.

${ }^{19}$ ЦДІАК України. Ф. 127. Оп. 885. Спр. 2. Арк. 1, 5.

${ }^{20}$ ЦДІАК України. Ф. 127. Оп. 894. Спр. 120. Арк. 44.

${ }^{21}$ Карпов С.М. Евгений Болховитинов как митрополит Киевский. Киев: Тип. Акц. Об-ва «Петр Барский в Киеве», 1914. С. 78.
} 
більшості церковнослужителів, відіслано у монастирі ${ }^{22}$. у 1866 р. кількість злочинних та невідповідних сану вчинків порівняно 3 попереднім роком дещо зменшилась. До консисторії таких справ надійшло 130, і за 52 єпархіальна адміністрація винесла звинувачувальні присуди. Серед них найсуворіші покарання отримали 3 священнослужителі, яких перевели в причетники, та 4 церковнослужителі виключили 3 духовного стану ${ }^{23} .1875$ р. за результатами розгляду 95 справ консисторія визнала провини за 27-ма особами. Загалом, митрополит повідомляв Св. Синоду, що духовенство єпархії поводило себе «соответственно своего звания», докладало максимум можливих зусиль для повчання парафіян істинам віри, ревно здійснювало богослужіння, завзято ставилося до свого учительського обов'язку, слідкувало за ставленням вірян до церкви, ближніх, зміцнювало віру, відновлювало добрі стосунки у сім'ях, застерігало від відвернення від православ'я ${ }^{24}$. У 1881 р. на розгляді Київської духовної консисторії перебувало 468 справ (включаючи ті, що залишилися з минулих років) про негідні вчинки духовенства. 3 них остаточно вирішено 346: визнано винними та покарано 40 осіб, що складало 1,2\% від усієї чисельності білого та чорного духовенства єпархії. Найсуворіші покарання були такі: 2 священики переведено на нижчі посади, 20 причетників виключено 3 кліру, 1 священик, 1 ієродиякон, 1 причетник отримали єпитимію у монастирі. Цей показник був відчутно нижчим порівняно $з$ двома попередніми роками: у 1879 р. покарано 50 членів причтів, а у 1880 р. - $118^{25}$. у 1886 р. $з 2976$ священно- та церковнослужителів єпархії за різні порушення було засуджено 25 осіб, що складало 0,8\% від загальної чисельності кліриків ${ }^{26}$, а в 1900 р. різних покарань зазнав 21 представник духовенства Київщини ${ }^{27}$, що становило також менше 1\%. При цьому варто наголосити, що за світським законодавством переважна більшість справ не були б порушені за відсутністю складу злочину, а розглядалися винятково становим церковним судом.

у середовищі парафіяльного духовенства білыше порушень здійснювалося церковнослужителями. Це відзначала і єпархіальна адміністрація. Зокрема, у звіті про стан єпархії за 1865 р. митрополит Арсеній (Москвін) зауважував, що випадки «порушення благопристойності» траплялися в більшості серед причетників, що пояснював «почасти від грубощів сімейного укладу», а найчастіше через «грубе селянське середовище» ${ }^{28}$. У звіті про стан Київської єпархії за 1904 р., причиною невідповідної поведінки нижчих членів кліру виступав невисокий моральний рівень останніх, у наслідок чого в них було слабше розвинене почуття відповідальності та порядності ${ }^{29}$.

\footnotetext{
${ }^{22}$ ЦДІАК України. Ф. 127. Оп. 1023. Спр. 180. Арк. 3.

${ }^{23}$ ЦДІАК України. Ф. 127. Оп. 954. Спр. 50. Арк. 784-785.

${ }^{24}$ ЦДІАК України. Ф. 127. Оп. 1023. Спр. 84. Арк. 7-8.

${ }^{25}$ Памятная книжка Киевской епархии: историко-статистические сведения об учреждениях духовного ведомства Киевской епархии, статистические списки церквей епархии и общие статистические сведения по всем сторонам епархиальной церковно-религиозной жизни / сост. А. В-нов, В. Антонов. Киев: Типография Г.Т. Корчак-Новицкого, 1882. С. 239.

${ }^{26}$ Опря Б.О. Повсякденне життя православного парафіяльного сільського духовенства... Арк. 48.

${ }^{27}$ Опря А.В. Православне духовенство в реформаційному та національно-визвольному русі України (1900 лютий 1917 р.). Кам'янець-Подільський: Оіюм, 2008. С. 32.

${ }^{28}$ ЦДІАК України. Ф. 127. Оп. 1023. Спр. 180. Арк. 3.

${ }^{29}$ Опря Б.О. Повсякденне життя православного парафіяльного сільського духовенства... Арк. 49.
} 
Важливе значення для підтримки морального рівня парафіяльного духовенства мав інститут благочинних. Саме на благочинних покладався обов'язок контролю за поведінкою підзвітного духовенства. Це закріплювалося в «Уставе духовных консисторий» ${ }^{30}$. Окрім того, посиленого контролю вимагали київські митрополити. Зокрема, у 1824 р. митрополит Євгеній (Болховітінов) видав розпорядження, яке вимагало від благочинних, щоб вони «о происходящих в духовенстве неблагопристойных поступках, стыд, нарекание и унижение наносящих духовному сану, со всею верностью доносили епархиальному архиерею - в противном случае их самих подвергать тем же взысканиям, каким бы подлежали самые виновные, от потачки их впадающие в порок» ${ }^{31}$. За неналежне виконання обов'язків благочинний підлягав покаранню. Так, на сторінках «Киевских епархиальных ведомостей» за 1879 р. повідомлялося про звільнення 3 посади благочинного 5-го округу Таращанського повіту священика с. Черепина за недонесення про здійснення незаконного шлюбу у його парафії ${ }^{32}$

Здійснена нами систематизація судових справ за матеріалами 127 фонду «Київська духовна консисторія» (за винятком 784 справ, переважну більшість 3 яких складають стосунки всередині кліру, де чітко не вказується, хто з членів причту порушник), виглядає $\mathrm{TaK}^{33}$ :

\begin{tabular}{|c|c|c|c|c|c|c|}
\hline Роки & Священники & Диякони & Дячки & Паламарі & Псаломщики & Всього \\
\hline $1800-1809$ & 376 & 13 & 76 & 31 & - & 496 \\
\hline $1810-1819$ & 334 & 27 & 71 & 37 & - & 469 \\
\hline $1820-1829$ & 396 & 39 & 83 & 45 & - & 563 \\
\hline $1830-1839$ & 321 & 40 & 63 & 21 & - & 445 \\
\hline $1840-1849$ & 602 & 105 & 221 & 76 & 1 & 1005 \\
\hline $1850-1859$ & 599 & 96 & 263 & 134 & - & 1092 \\
\hline $1860-1869$ & 648 & 53 & 232 & 91 & 1 & 1025 \\
\hline $1870-1879$ & 451 & 35 & 111 & 49 & 4 & 650 \\
\hline $1880-1889$ & 193 & 9 & 43 & 8 & 11 & 264 \\
\hline $1890-1899$ & 233 & 10 & 3 & 2 & 72 & 320 \\
\hline $1900-1909$ & 572 & 29 & 1 & - & 344 & 946 \\
\hline $1910-1917$ & 534 & 40 & - & - & 193 & 767 \\
\hline Всього & 5259 & 496 & 1167 & 494 & 626 & 8042 \\
\hline
\end{tabular}

3 наведених даних видно, що з 8042 справ за 1800-1917 pp. 3122 (38,8\%) припали на 4060-ті роки XIX ст., тобто період дії «Положення про забезпечення православного сільського духовенства землею, будинками і одноразовою допомогою» 1842 р., яке істотно вплинуло на погіршення відносин між духовенством і мирянами. Адже документ вимагав виділення причтам 33 дес. землі, обробітку священицьких наділів, забезпечення священно- i

\footnotetext{
${ }^{30}$ Устав духовных консисторий... С. 38, 64.

${ }^{31}$ Орловский П. Деятельность митрополита Евгения по управлению Киевскою епархиею // Киевские епархиальные ведомости. 1901. № 13. С. 600.

${ }^{32}$ Распоряжения епархиального начальства // Киевские епархиальные ведомости. 1879. № 25. С. 11.

${ }_{33}^{33}$ Підраховано автором за тематичними покажчиками до 127 фонду «Київська духовна консисторія» ЩДІАК України.
} 
церковнослужителів житлом, господарськими будівлями. Водночас найбільший відсоток справ - 5259 (65,4\%) від загальної кількості, що розглядались консисторією, стосувалася священиків. Це можна пояснити досить жорстким контролем церковної адміністрації за священнослужителями і зобов'язанням селян обробляти лише священицький наділ. Причетників стосувалося 2287 справ, дияконів - 496, що у відсотковому співвідношенні складає відповідно 28,4\% і 6,2\%.

Матеріали фонду Київської духовної консисторії за 1800-1917 рр. дають змогу з'ясувати найпоширеніші правопорушення кліриків. Ми погоджуємося з В. Мешою ${ }^{34}$, що на першому місці були конфліктні ситуації з парафіянами (побиття, образи, грубе ставлення, хабарництво, крадіжки, невиконання треб, захоплення землі та майна, несплата боргів та ін.). Однак, за нашими підрахунками, друге місце займали порушення у побуті (пияцтво, сімейні стосунки, гра в карти, сварки, позашлюбні зв'язки), третє - зловживання службовим становищем (привласнення церковного майна) та стосунки між священиками та церковнослужителями (скарги, образи, сварки, бійки, несправедливий розподіл прибутків, церковної землі й ін.).

Поширеним порушенням серед парафіяльного духовенства було пияцтво. Нерідко самі парафіяни та народні традиції підштовхували членів причту до вживання алкоголю. Духовенство обходило будинки парафіян на великі церковні свята, як-от Водохреща, Різдво, Пасху, що мали давню традицію. Селяни готувалися до прийому гостей: готували святковий стіл, купували вино, горілку. Відвідування будинків часто супроводжувалося частуванням священно-, церковнослужителів. Також священику доводилось проводити обряди у будинках вірян, наприклад, хрещення, прийняття передсмертної сповіді, відспівування. Окрім традиційної плати за треби господар запрошував священно- і церковнослужителів на частування зі спільним вживанням алкоголю. У селянському середовищі використання алкогольних напоїв було одним із складників розрахунку за роботу, а пригощання чаркою духовенства більше сприймалося як подяка. Та й під час спільного застілля встановлювалися більш доброзичливі відносини і священнослужитель ставав «своїм» у селянському оточенні.

Проте саме пияцтво духовних осіб не завжди підлягало покаранню. Церковна адміністрація у першу чергу реагувала на девіантну поведінку, що часто супроводжувала вживання спиртних напоїв. До консисторії надходило чимало скарг на священно- i церковнослужителів, які поводили себе неналежним чином у стані алкогольного сп'яніння. у 1882 р. благочинний 6-го округу Таращанського повіту повідомляв пристава 3 стану, що священик с. Чоповичі Радомишльського повіту Д. Симонович, прибувши у с. Голодьки Таращанського повіту для збору врожаю, по завершенню роботи у стані алкогольного сп'яніння «бегал обнажённый по полю и кладбищу» ${ }^{35}$. До того ж навіть здійснював спробу самогубства. Консисторія одразу прийняла рішення заборонити йому священнослужіння, а парафію тимчасово доручити сусідньому священику. В ході слідства було з'ясовано, що такі «случаи умопомешательства» траплялася винятково у нетверезому стані, а спроба самогубства вже друга. Д. Симоновича було переведено на причетницьку посаду, а священнослужіння Св. Синод дозволив лише у 1887 р. Варто зауважити, що у 1892 р. в

\footnotetext{
${ }^{34}$ Меша В.Г. Правовий статус духовенства України другої половини XIX століття... С. 169.

${ }^{35}$ ЦДІАК України. Ф. 127. Оп. 954. Спр. 173. Арк. 1-3.
} 
рапорті благочинного 3 округу Бердичівського повіту священик м. Білилівки Д. Симонович характеризувався винятково позитивно: «поведения очень хорошего». Священнослужитель мав власну бібліотеку та приділяв увагу читанню більше ніж інші священики ${ }^{36}$.

у 1883 р. на сторінках єпархіального часопису повідомлялося, що священика с. Торчин Радомишльського повіту П. Ципріановича за «нетрезвую жизнь» церковна адміністрація покарала позбавленням парафії і переведенням на причетницьку посаду, із забороною священнослужіння «до искреннего раскаяния и исправления» ${ }^{37}$. У надмірному зловживанні алкоголю обвинувачувався священик с. Березівки Уманського повіту Л. Маковський. У скарзі віряни зазначали, що священик у стані сп'яніння часто виконував треби «отступая при этом от установленных церковных правил», не завжди проводив богослужіння не тільки у недільні дні, а й у свята. Від постійного пияцтва священнослужитель «ведет себя невменяемо, ходит по селу без шапки, с растрёпанными волосами і каждого просит купить водки ... прихожане потеряли к нему всякое уважение ${ }^{38}$. у 1885 р. Л. Маковського, позбавивши парафії та заборонивши священнослужіння, відправили до Богуславського монастиря до «раскаяния и исправления» ${ }^{39}$. Заштатного священика с. Рижавка Уманського повіту М. Липківського за часті відвідини різних парафій сусідньої Подільської єпархії, де пиячив, як вдівця та безсімейного назавжди відправили до Виноградівського монастиря ${ }^{40}$.

У 1899 р. та 1900 р. перебував під слідством за звинуваченням у пияцтві священик м. Радомишля I. Котляр. Проте тоді ця інформація не була доведеною. Вчергове консисторія розглядала інформацію про нетверезість священнослужителя у наступному 1901 р. і було прийнято рішення про відправлення І. Котляра на епітимію до монастиря ${ }^{41}$. Дячка с. Талалай Бердичівського повіту І. Корендовича за неналежне ставлення до своїх обов'язків, пияцтво, немиролюбні відносини з вірянами було покарано перебуванням у Києво-Видубицькому монастирі терміном на один місяць. За умови позитивного відгуку настоятеля монастиря, І. Корендович залишався на дячківській посаді парафії с. Талалай, але мав перебувати під особливим наглядом місцевого благочинного ${ }^{42}$. У 1902 р. за пияцтво та грубість 3 парафіянами псаломщика с. Заліське Звенигородського повіту I. Баккалинського було виключено 3 духовного стану ${ }^{43}$.

3 іншого боку віряни, засуджуючи пияцтво окремих священно- і церковнослужителів, у значно більшій мірі були схильні до вживання алкоголю. Саме духовенство виступало ініціатором створення товариств тверезості, беручи на себе обов'язок боротьби з цією суспільною вадою.

Деякі священно- і церковнослужителі мали пристрасть до азартних ігор. Зокрема, у 1964 р. благочинний 3-го округу Васильківського повіту повідомляв митрополита Київського Арсенія про те, що іноді клірики його округу дозволяли собі гру в карти. На це

\footnotetext{
${ }^{36}$ ЦДІАК України. Ф. 127. Оп. 954. Спр. 173. Арк. 11-298.

${ }^{37}$ Распоряжения и извещения епархиального начальства // Киевские епархиальные ведомости. 1883. № 23. C. 464.

${ }^{38}$ ЦДІАК України. Ф. 442. Оп. 615. Спр. 130. Арк. 1-3.

${ }^{39}$ ЦДІАК України. Ф. 442. Оп. 615. Спр. 130. Арк. 9.

${ }^{40}$ ЦДІАК України. Ф. 127. Оп. 846. Спр. 74. Арк. 3.

${ }^{41}$ ЦДІАК України. Ф. 127. Оп. 955. Спр. 466. Арк. 1-12.

${ }^{42}$ ЦДІАК України. Ф. 127. Оп. 954. Спр. 183. Арк. 3-67.

${ }^{43}$ ЦДІАК України. Ф. 127. Оп. 876. Спр. 873. Арк. 111.
} 
митрополит вимагав від духовенства єпархії «употребление карт... из домов своих изгнать навсегда» ${ }^{44}$.

Інколи священики, бажаючи поживитися за рахунок парафіян, вдавалися до вимагання плати за треби не рахуючись 3 достатком того чи іншого вірянина. Так, у 1833 р. парафіяни с. Хлипнівки Звенигородського повіту скаржилися на місцевого священика Лисянського за вимагання високої оплати треб, який $з$ цієї причини відмовлявся навіть відспівувати покійних і сповідувати вірян. За результатами слідства було прийнято рішення позбавити священнослужителя парафії і як вдівця відправити назавжди до монастиря. Проте за проханням священика митрополит Євгеній (Болховітінов) пом'якшив покарання, залишивши його за штатом на утриманні дітей ${ }^{45}$.

У 1875 р. священик с. Юшок Київського повіту Тарасевич відмовився відспівувати онуку місцевого селянина П. Горбача, бо він не обробляв земельний наділ священнослужителя. При розслідуванні віряни заявляли, що Тарасевич здійснює їм різні утиски за те, що вони не хочуть безоплатно обробляти його землю. Консисторія доручила благочинному провести розслідування, проте незалежно від його результатів Тарасевичу було наказано протягом двомісячного терміну знайти собі іншу парафію ${ }^{46}$.

у 1886 р. Київська духовна консисторія розглянула справу священика с. Ромейківки Звенигородського повіту Д. Мельниковського, якого віряни звинувачували у вимаганні плат за треби. Священнослужителя позбавили парафії та відправили на місяць до Корсунського монастиря. Також церковна адміністрація на шпальтах «Киевских епархиальных ведомостей» закликала духовенство не допускати подібних випадків ${ }^{47}$.

у 1909 р. надійшла колективна скарга, підписана 15-ма вірянами с. Рубченки Сквирського повіту, до єпископа канівського Інокентія на священика К. Завадського. Селяни зазначали, що священнослужитель «требует с нас непосильные, не соображаясь с достатком каждого прихожанина побори за требы: установил таксу в 5 руб. за брак». Якщо хтось не може заплатити то тих відправляє «до штундистов или ксёндза, говорит что даром повенчают» ${ }^{48}$.

Проте не завжди подібні скарги носили вмотивований характер. Зокрема у 1902 p. Св. Синод розглядав скаргу вірян с. Колонщини Київського повіту на місцевого священика, якого звинувачували у вимаганнях за здійснення треб. Однак ці звинувачення не підтвердилися ${ }^{49}$.

Єпархіальна адміністрація боролася з безпідставними доносами та наклепами у середовищі парафіяльного духовенства. у 1869 р. це питання навіть розглядалося єпархіальним з'їздом, де з метою попередження подібних вчинків, прийнято рішення про суворішу відповідальність кліриків ${ }^{50}$. Проте звичайно такі випадки траплялися й у подальшому. Зокрема, у 1884 р. диякона Преображенської церкви с. Лебедина

\footnotetext{
${ }^{44}$ ЦДІАК України. Ф. 127. Оп. 667. Спр. 194. Арк. 2-4.

${ }^{45}$ ЦДІАК України. Ф. 127. Оп. 121. Спр. 50. Арк. 24-59.

${ }^{46}$ ЦДІАК України. Ф. 442. Оп. 54. Спр. 216. Арк. 1-4.

${ }^{47}$ По поводу вымогательства платы при совершении треб // Киевские епархиальные ведомости. 1886. № 8 . C. 346.

${ }^{48}$ ЦДІАК України. Ф. 127. Оп. 1065. Спр. 235. Арк. 1-2.

${ }^{49}$ ЦДІАК України. Ф. 127. Оп. 876. Спр. 873. Арк. 17.

${ }^{50}$ Протоколы занятий киевского епархиального съезда // Киевские епархиальные ведомости. 1869. № 21. C. 155.
} 
Чигиринського повіту I. Радчевського було покарано місячним перебуванням у Виноградівському монастирі за підбурювання вірян до подання безпідставного прохання про звільнення священика Георгіївської церкви С. Шостацького 3 метою зайняття його парафії ${ }^{51}$

Традиційними для церковного суду були справи про незаконне вінчання. Зокрема, священика І. Павловича за вінчання осіб з іншої парафії без належних документів, до того ж неодноразово, було звільнено за штат на власне утримання. А за заперечення провини та видачу фальшивих свідоцтв священику було заборонено священнослужіння, носіння ряси і рукоблагословіння, а благочинному наказано забрати ставленицьку грамоту та документи 3 церкви ${ }^{52}$.

На сторінках «Киевских епархиальных ведомостей» за 1883 р. повідомлялося про покарання двох причтів за недотримання правил одруження. Один із причтів м. Києва за вінчання неповнолітньої нареченої було покарано штрафом із внесенням до формуляру. А священика однієї з парафій Радомишльського повіту за вінчання осіб з інших парафій без дотримання відповідних правил і до того ж у нічний час єпархіальна адміністрація покарала місячним перебуванням у монастирі із внесенням цього покарання у формулярних список священика ${ }^{53}$. Інформуючи про покарання кліриків на сторінках єпархіального часопису церковне керівництво намагалося утримати священнослужителів від подібних вчинків.

За вінчання осіб, які були «у 3-й степени родства» (рідні дядько та племінниця) без визначених законом документів, у 1904 р. було покарано причт Іоано-Златоустівської церкви м. Києва. Консисторія прийняла рішення, беручи до уваги розкаяння священика К. Королькова та його «беспорочную службу», пом'якшити покарання та відправити на два місяці до Києво-Видубицького монастиря. Диякон Н. Левитський отримав сувору догану без занесення до формуляру. Проте, у зв'язку з хрещенням спадкоємщя престолу цесаревича і князя Олексія Миколайовича, священика К. Королькова було звільнено від покарання ${ }^{54}$.

Досить рідко, але все ж траплялися випадки коли клірики мали недозволені стосунки. Наприклад, у 1841 р. до київського генерал-губернатора надійшов рапорт від Липовецького земського суду, де зазначалося, що священик с. Шабастівки Крижановский «склонил на блудную жизнь тамошнюю крестьянскую девку Марию Журавлеву», яка до того ж завагітніла. Усвідомлюючи наслідки, священнослужитель «предлагал средства к отравлению находящегося в внутре ребёнка» ${ }^{55}$. Єпископ чигиринський Ієремія у відповідь на лист генерал-губернатора доручив консисторії негайно провести розслідування, а клірику було заборонено священнослужіння.

у 1843 р. назавжди було заборонено священнослужіння і переведено у причетники диякона с. Матусів Черкаського повіту М. Кейзера. Будучи вдівцем, він мав стосунки 3 донькою священика А. Виноградською, яка до того ж була виключена з духовного стану «за распутство $»^{56}$.

\footnotetext{
${ }^{51}$ Дисциплинарное взыскание // Киевские епархиальные ведомости. 1884. № 17. С. 750.

${ }^{52}$ ЦДІАК України. Ф. 127. Оп. 840. Спр. 388. Арк. 30-31.

${ }^{53}$ Распоряжения и извещения епархиального начальства // Киевские епархиальные ведомости. 1883. № 23. C. 464.

${ }^{54}$ ЦДІАК України. Ф. 127. Оп. 1053. Спр. 151. Арк. 1-5.

${ }_{55}^{55}$ ЦІАК України. Ф. 442. Оп. 1. Спр. 4216. Арк. 1.

${ }^{56}$ ЦДІАК України. Ф. 127. Оп. 885. Спр. 8. Арк. 7.
} 
Священик м. Рожів Радомишльського повіту Д. Борзаковський за «блудную жизнь» 3 дворянкою А. Здановською у 1847 р. був переведений на причетницьку посаду строком на два роки. По завершенню цього терміну мало розглядатися питання про можливість повернення священицького місця. Проте клірик «навлек на себя еще больше подозрений», тому прохання Д. Борзаковського про дозвіл священнослужіння у 1852, 1856, 1857 роках не задовольнялися. Митрополит вважав це «оскорбительным для святости служения алтарю Господнему», тим більше знаходячись на дячківській посаді він «не одобряется в поведении благочинным» ${ }^{57}$.

Якщо священнослужитель за недозволені стосунки після відбування покарання залишався у духовному стані принаймні на церковнослужительській посаді, то нижчим членам кліру це однозначно загрожувало виключенням з духовного стану. Зокрема, у 1873 р. за «преступные» стосунки 3 солдаткою В.Дирдовою паламаря с. Деренковця Черкаського повіту М. Григоровича було виключено 3 духовного стану ${ }^{58}$. Таку ж санкцію у 1900 р. було застосовано і до псаломщика с. Плисецького Васильківського повіту М. Шпаковського. Церковнослужитель, будучи неодруженим, мав стосунки з селянкою М. Бондарчуковою, у результаті яких народилася дитина. Також суд задовольнив прохання матері про сплату 2 руб. на місяць на утримання доньки до їі повноліття або заміжжя ${ }^{59}$.

Траплялися випадки домашнього насильства з боку священиків, що часом призводило до трагічних наслідків. Так, у 1838 р. світський суд почав розгляд справи священика с. Макалевич Радомишльського повіту А. Суського. Побиття останнім вагітної дружини спричинило передчасні пологи, під час яких жінка померла. Остаточну крапку у цій справі слідство не поставило, оскільки у 1839 р. помер А. Суський. Сиротами залишилося троє дітей ${ }^{60}$.

Звинувачували в пияцтві, неодноразовому побитті дружини і священика с. Жидовця А. Черняховського. А після жорстокого побиття сина наступного дня той покінчив життя самогубством. Виявилося, що вночі 30 квітня 1875 р. священик обвінчав невідому пару, за що отримав 56 руб. Ці кошти син украв, що і стало для батька причиною нанесення важких побоїв. Про результати слідства Київський митрополит повідомляв Св. Синод, зазначаючи, що самогубство сина за показами свідків було наслідком «жестокого обращения с ним и тяжких побоев... причиненные ему накануне дня самоубийства» ${ }^{61}$. Покази свідків підтверджувалися і медичним оглядом. А. Черняховського було позбавлено сану, а суд виніс вирок за яким колишній священик мав один рік провести у в'язниці, потім ще один рік перебувати під наглядом поліції, без права залишати місце проживання без дозволу правоохоронних органів ${ }^{62}$.

у 1887 р. благочинний 2-го округу Київського повіту В. Сікорський рапортував єпархіальній адміністрації, що священик сГрузької А. Василевський «давно известен немирною жизнью в своем семействе... со временем он все чаще и чаще начал подвергать всякого

\footnotetext{
${ }^{57}$ ЦДІАК України. Ф. 127. Оп. 885. Спр. 1. Арк. 323-326.

${ }^{58}$ ЦДІАК України. Ф. 127. Оп. 845. Спр. 300. Арк. 21.

${ }^{59}$ ЦДІАК України. Ф. 127. Оп. 954. Спр. 477. Арк. 10-19.

${ }^{60}$ ЦДІАК України. Ф. 127. Оп. 955. Спр. 11. Арк. 1-52.

${ }^{61}$ ЦДІАК України. Ф. 127. Оп. 919. Спр. 317. Арк. 43.

${ }^{62}$ ЦДІАК України. Ф. 127. Оп. 919. Спр. 317. Арк. 45-46.
} 
рода истязаниям свою жену» ${ }^{63}$. Благочинницька рада округу з метою напоумлення священика у серпні 1884 р. зробила йому «должное внушение о его неблагоповедении», яке мало подіяло на священнослужителя. Оскільки 3 причини жорстокого поводження в кінці 1885 р. дружина 3 дітьми змушені були втікати з дому. Благочинний черговий раз викликав священика, проте й надалі знущання продовжилися, і дружина вимушена була поїхати в Київ до батьків. Врешті дійшло до того, що А. Василевський ще більше посилив знущання над дружиною, систематично сік різками та бив палицями. Тому благочинний наголошував на необхідності термінових суворих заходів для його виправлення та неможливості залишення у грузянській парафії «без явного ущербу для благочестья прихожан» ${ }^{64}$. Консисторія прийняла рішення негайно позбавити його парафії, заборонити священнослужіння, позбавити священицького сану та залишити у духовному відомстві на церковнослужительській посаді. У подальшому А. Василевський домагався повернення священицького сану, проте церковна адміністрація, будучи категоричною, його численні прохання не задовольняла, залишивши на місці причетника ${ }^{65}$.

Проте іноді система покарань не досягала головної мети - перевиховання священно- і церковнослужителів. Адже траплялися непоодинокі випадки, коли клірики засуджувалися церковним судом повторно. Зокрема, диякон с. Турія Чигиринського повіту Г. Завиновський у клірових відомостях характеризувався як «буян и пьяница», двічі засуджувався консисторією за конфлікти з парафіянами та священником, надмірне зловживання алкоголем. За це втратив місце у с. Млієв Черкаського повіту, також йому було заборонено священнослужіння та покарано перебуванням у монастирі терміном на один місяць. Згодом Г. Завиновський був переведений до с. Турія Чигиринського повіту на псаломщицьке місце. Проте дисциплінарні заходи єпархіальної адміністрації мало діяли на церковнослужителя. За подібну поведінку Г. Завиновського, консисторія у 1887 р. вже втретє і востаннє вирішила застосувати виправні заходи та дати шанс на виправлення. Клірик був відправлений на три місяці до Межигірського монастиря під суворий нагляд настоятеля «для употребления на чёрных работах». У рішенні церковної адміністрації обумовлювалося, що Г.Завиновський зможе просити про нове місце лише за умови позитивного відгуку настоятеля монастиря, інакше буде виключений 3 духовного стану ${ }^{66}$.

Церковні покарання були м'якими. Часто церковна адміністрація намагалася вплинути на кліриків настановами. Зокрема, це відзначав у звіті про стан єпархії за 1865 р. Арсеній (Москвін). Митрополит зауважував щодо припинення девіантної поведінки - крім штрафів на користь єпархіального опікунства, доган та інших заходів церковна адміністрація використовувала настанови та поради духовенству ${ }^{67}$. За відсутності бажання змінюватися, щирого розкаяння винного, система покарань залишалася малодієвою. у парафії залишалися особи, які не завжди відповідали священнослужительському покликанню, а якщо вони й позбавлялися сану, то зазвичай переводилися на нижчі церковні посади.

М'якість церковного судочинства відзначала і світська влада. Особливої гостроти

\footnotetext{
${ }^{63}$ ЦДІАК України. Ф. 127. Оп. 954. Спр. 257. Арк. 12.

${ }^{64}$ ЦДІАК України. Ф. 127. Оп. 954. Спр. 257. Арк. 12-14.

${ }^{65}$ ЦДІАК України. Ф. 127. Оп. 954. Спр. 257. Арк. 85-184.

${ }^{66}$ ЦДІАК України. Ф. 127. Оп. 954. Спр. 252. Арк. 65-66.

${ }^{67}$ ЦДІАК України. Ф. 127. Оп. 1023. Спр. 180. Арк. 3.
} 
питання морального рівня православного кліру на Правобережжі набувало у зв'язку із впливами католицизму. Зокрема, в середині 60-х років XIX ст. генерал-губернатор повідомляв міністра внутрішніх справ: «Православное духовенство, в особенности сельское, к сожалению по нравственному состоянию не находится на той степени, на какой желательно его видеть здесь в виду иноверия ${ }^{68}$. Та відзначав, що для його підвищення необхідно звернути увагу на моральне виховання студентів духовних навчальних закладів. Максимально розважливо підходити до вибору парафіяльних священиків. Пропонував надати більше свободи єпархіальним адміністраціям у розгляді та вирішенні справ про негідні вчинки осіб духовного стану. На думку генерал-губернатора, подібні справи вирішувалися поблажливо та повільно, а відтак, іноді у парафіях залишалися недостойні священно- та церковнослужителі, що давало можливість іновірцям очорнювати все православне духовенство. Тому він пропонував, щоб єпархіальна влада, не чекаючи суду консисторії, без будь-якої поблажливості видаляла 3 парафій священиків, які поводились негідно і невідповідно до сану. Водночас зазначав, що для морального піднесення духовенства необхідне належне матеріальне забезпечення та встановлення грошового збору замість обов'язкових робіт вірян, встановлених за «Положенням...» 1842 p. $^{69}$

Таким чином, правопорушення кліриків в основному стосувалися виконання ними службових обов'язків або неналежної моральної поведінки. Проте, не варто перебільшувати масштаб протиправних вчинків духовенства. Кримінальні злочини священно- i церковнослужителі майже не здійснювали. А церковним судом у другій половині XIX ст. засуджувався приблизно 1\% від загальної кількості парафіяльного духовенства Київської єпархії. До того ж варто наголосити, що переважна більшість священно- i церковнослужителів були правопорушниками тільки по церковному суду, який карав кліриків за незначні проступки. Якщо сварки, образи, конфлікти зі штовханиною, пияцтво, дрібні крадіжки, наприклад, у селянському середовищі не вважалося правопорушенням і не були предметом судового розгляду, то священику це, як мінімум, загрожувало доганою, штрафом, тимчасовим перебуванням у монастирі, а то й переведенням на деякий час на причетницьку посаду. Абсолютна більшість парафіяльних кліриків належним чином виконували свої обов'язки, не викликаючи нарікань з боку церковної адміністрації та вірян. Навіть незначна невідповідність соціальної ролі викликала швидку реакцію найперше єпархіального керівництва та пастви, адже одиничний проступок окремого клірика кидав тінь на весь духовний стан, подавав негативний приклад для вірян.

Vitalii Tatsiienko

\section{Deviant behaviour of the Orthodox parish clergy of the Kyiv eparchy in the XIX - early XX centuries}

Abstract: The article considers the deviant behaviour of the Orthodox parish clergy of the Kyiv eparchy in the XIX - early XX centuries. It has been noted that a vast majority of cases relating to clergymen were subject not to a secular but to a separate church court. The most

\footnotetext{
${ }^{68}$ ЦДІАК України. Ф. 442. Оп. 815. Спр. 118. Арк. 9-10.

${ }^{69}$ ЦДІАК України. Ф. 442. Оп. 815. Спр. 118. Арк. 10.
} 
common violations of canonical and social norms by churchmen and the sanctions of church administration have been established. The offenses of the churchmen were mainly related to their job duties or improper moral behaviour. Representatives of the parish clergy were most often accused of alcoholism, conflicts with parishioners, an "illegal" character of a religious rite and extortion. The most common sanctions of the eparchial administration were fines and a temporary ban on the church service with a transfer to junior deacons or sending to a monastery. The eparchial administration noted that in the parish clergy environment more violations were committed by clergy. Church punishments were lenient. It is noted that sometimes the system of punishments did not achieve the main goal - the reeducation of clergy. There were many cases when the churchmen were convicted by the church court again.

However, the scale of the clergy's offenses should not be exaggerated. The clergy almost did not commit criminal offenses. In the second half of the XIX century about $1 \%$ of the total number of parish clergy of the Kyiv eparchy was convicted by the church court. It is noted that a vast majority of the clergy were offenders only in accordance with the church court verdict, which punished churchmen even for minor misdemeanors.

The inconsistency of the clergy with a social role provoked a quick reaction of the eparchial administration, because a single transgression of a churchman cast a shadow on the whole spiritual state, set a negative example for believers.

Keywords: Orthodox parish clergy, deviant behaviour, church court, Kyiv eparchy, spiritual consistory 